\title{
Root rot toxines as a factor in the selection of resistant forms of oats in vitro
}

Lugovtsova S.Yu., Neshumaeva N.A., Stupko V.Yu., Zobova N.V.

Krasnoyarsk Agricultural Research Institute, Federal Research Center "Krasnoyarsk Scientific Center of the SB of the RAS", Krasnoyarsk, Russia

E-mail: nneshumaeva@list.ru

Key message. The oat regenerants with resistance to the Fusarium mycotoxin influence were obtained in vitro on selective media with different concentrations of root rot culture filtrate.

Keywords: mycotoxines, in vitro, regenerants, root rots, culture filtrate

Fusarium blight of oat, inducted by fungi of the genus Fusarium, that produce toxin, is the one of the most frequently reason of yield and seed quality decrease, that made the final agrarian sector product harmful for human and animal health. Method of screening on selective media containing root rot toxins can be used in selection for resistance against fusarium blight. The investigation influence on growth and development of spring oat callus culture of metabolites of different species of pathogens, mentioned above, was conducted in KrasARI.

Classic methods of tissue cultivation in vitro were used. Callusogenesis was induced in immature oat embryo culture of different varieties (Tubinskij, Sayan, Kazyr, Sel'ma, Talisman, Zolotoj pochatok, Golec, Tyumenskij golozernyj) on Murashige-Skoog medium with 3mg/l 2.4-D and $2 \mathrm{mg} / 1$ IAA. After 30 days calluses were moved to proliferation medium with a half level of 2.4-D. The culture filtrate $(\mathrm{CF})$ (F. poae, F. eqiseti, F. oxysporum and $F$. sporotrichioides) in different concentrations $(30 \%, 40 \%, 50 \%)$ was added to experimental media.

The evaluation of potential capability of selection of plant-regenerants with resistance to micromycete toxic methabolites detected that bioactive substances in culture broth had inhibited the callus proliferation processes and regenerant development of all investigated samples but to a different degree.

The Kazyr variety was considered to be the most tolerant to all root rot toxic metabolites, involved into present investigation, according to the data on several parameters (prolifereation, stem formation and rhizogenesis levels). The difference in the strength of the influence of involved fungi isolates on callus culture under all levels of CF in medium indicates that the CF of $F$. poae is the most aggressive. The regenerants, developed on selective media (61 plants with $\mathrm{CF}$ of $F$. poae and $72-$ with $\mathrm{CF}$ of $F$. oxysporum), are of practice interest on own as well as sources of resistance for selection process.

\section{Токсины корневых гнилей, как фактор отбора устойчивых форм овса в культуре in vitro} Луговиова С.Ю., Нешумаева Н.А., Ступко В.Ю., Зобова Н.В.

Красноярский научно-исследовательский институт сельского хозяйства, Федеральный исследовательский центр «Красноярский научный центр СО РАН», Красноярск, Россия

\begin{abstract}
Аннотация. На селективных средах, содержащих разные конщентрации культуральных фильтратов корневых гнилей, в культуре in vitro получены регенеранты овса, устойчивые к воздействию микотоксинов рода Fияагіит. Ключевые слова: микотоксины, in vitro, регенеранты, корневые гнили, культуральный фильтрат
\end{abstract}

Фузариоз зерна овса, возбудителями которого являются токсиногенные грибы из p. Fusarium является частой причиной снижения урожайности и качества зерна, делая конечную продукцию аграрного производства опасной для здоровья человека и сельскохозяйственных животных. В селекции на устойчивость к фузариозам может быть использован подход клеточного отбора на селективных средах с токсинами корневых гнилей. В КрасНИИСХ проведена работа по оценке влияния метаболитов разных видов указанных патогенов на рост и развитие каллусных культур форм ярового овса.

Использованы классические методы культивирования тканей in vitro. Каллусогенез индуцировали в культуре незрелых зародышей сортов овса (Тубинский, Саян, Казыр, Сельма, Талисман, Золотой початок, Голец, Тюменский голозерный) на среде Мурасиге-Скуга с добавлением 3 мг/л 2,4-Д и 2 мг/л ИУК. Через 30 дней каллусы пассировали на среду пролиферации со сниженным в два раза уровнем 2,4-Д. В опытный вариант среды добавляли культуральный фильтрат (КФ) (F. poae, F. eqiseti, F. oxysporum и F. sporotrichioides) в различных концентрациях $(30 \%, 40 \%, 50 \%)$.

Оценка возможности отбора растений-регенерантов, устойчивых к действию токсических метаболитов микромицетов, выявила, что биологически активные вещества, содержащиеся в культуральных жидкостях, оказывают ингибирующее действие на процессы пролиферации каллусов и образование регенерантов у всех исследуемых образцов, но в разной степени. Наиболее устойчивым к спектру примененных токсических метаболитов корневых гнилей по нескольким параметрам (пролиферация, стеблегенез и регенерация) по результатам испытаний в разные годы признан сорт Казыр. Отличия по силе воздействия использованных изолятов, проявившиеся на всех уровнях КФ, показало, что наиболее агрессивным является КФ $F$. роае. Регенеранты, полученные на селективных средах (61 растений с КФ F. роае и 72 - с КФ F. oxysporum), содержащих КФ данных патогенов, представляют большой практический интерес, как самостоятельные объекты, так и в качестве источников устойчивости в селекции. 